\title{
Green Operation Barriers of Malaysia Green Operators
}

\author{
Zeenat Begam Yusof1, Mariam Jamaludin² \\ ${ }^{1}$ Kulliyyah of Architecture and Environmental Design, \\ International Islamic University Malaysia, 50728 Kuala Lumpur, Malaysia \\ 2 Faculty of Architecture Planning and Surveying, \\ Universiti Teknologi MARA, 40450 Shah Alam, Selangor, Malaysia \\ zerovelocity7@yahoo.com
}

\begin{abstract}
Recently there has been a tremendous effort in greening the tourism industry due to its negative environmental impacts. The efforts of greening the green lodging industry in Malaysia is growing slowly due to the several barriers. The objective of this study is to determine the barriers that slowing the green hotels and resorts operation in Malaysia. This study employed qualitative method using interview technique. Five case studies were chosen and the environmental managers are interviewed. The findings identified 12 barriers. The barriers are categorized under significant, less significant and nonsignificant barriers that affecting lodging green operation in Peninsular Malaysia.

Keywords: Green practice; Barriers; Level of significance; Green operators

eISSN 2398-4279 @ 2018. The Authors. Published for AMER ABRA cE-Bs by e-International Publishing House, Ltd., UK. This is an open access article under the CC BY-NC-ND license (http://creativecommons.org/licenses/bync-nd/4.0/). Peer-review under responsibility of AMER (Association of Malaysian Environment-Behaviour Researchers), ABRA (Association of Behavioural Researchers on Asians) and $c E-B s$ (Centre for EnvironmentBehaviour Studies), Faculty of Architecture, Planning \& Surveying, Universiti Teknologi MARA, Malaysia.

DOI: https://doi.org/10.21834/ajqol.v3i9.79
\end{abstract}




\subsection{Introduction}

Currently environmental issues become interest of all countries due to the deterioration of the natural physical environment. Environmental pressures affect all the industries system including process, inputs and operation (Elkington 1992). Therefore, sustainable management practices become vital approach in managing industries (Claver-Cortes 2007). Many studies have shown that integration of environmental management system can reduce the negative impacts of the operation on the environment (Bonilla Priego \& Aviles Palacios, 2008; Ngai Weng, 2009).

Tourism and natural environment have very strong relationship. According to Mathieson (1982) natural environment is a core feature of tourism products. Basically, tourism industry are causing degradation of the natural environment due to several reasons such as the excessive use of natural resources, high numbers of tourist arrivals and over development of tourism facilities (Robinot \& Giannelloni, 2010).

Adhering to the negative impacts, the lodging industry taking further steps to become green industry. Lodging industry especially hoteliers are seriously taking part in greening the industry because of few driving factors. The driving factors are financial benefits which were studied by (Molina-Azorín et al 2009), ecological responsibility, competitiveness, legitimation studied by (Bansal 2000) and the emergence of green consumers mentioned by (Vikneswaran Nair \& Anantharajah, 2012). A study had confirmed that financial benefits and legitimation is the main driving factors that causing hoteliers to become green operators (Rahman et al, 2012).

The lodging industry in Malaysia is taking slow progress even though the reaping benefits are well acknowledged. According to T.Knowles (1999) "after two decades of such effort, however this 'greening' does not seem to be successful as originally hoped". This occurs due to the few barriers that hoteliers have to face in order to become green operators. There are several studies conducted regarding operation barriers and green operation barriers. The example of operation barriers studies are conducted by (Jauhari \& Rishi 2012: Jayawardena et al 2013) and the example of green operation barriers studies were conducted by (Chan 2008; Vikneswaran Nair et al, 2012; Kamalulariffin et al, 2013). However, studies regarding green operation in Malaysia are rarely address and limited (KamalulAriffin et al., 2013).

Therefore, this study is conducted to determine the green operation barriers of green hotels and resorts in Malaysia. This study offers a contribution to the field of knowledge regarding green operation barriers in the hotel industry especially in Malaysia. The findings of this research can also give some ideas to Malaysian Association Hotels (MAH) and green hoteliers to find the solution for the barriers.

\subsection{Literature Review}

Environmental movement started in 1970, but it was recognized in 1992 during the Earth Summit in Rio De Janeiro, Brazil. During the conference, 172 nation work together to produce environmentally sound framework in order to minimize the impacts of industries on the environment (Imran Rahman 2012). The concept of sustainability was introduced during the 
conference. Sustainability is well defined by the Brundtland Report which is "development that meets the needs of the present without compromising the ability of future generations in order to meet their own needs" (Brundtland 1987).

Later the concept of sustainability was integrated in the hospitality industry. Hospitality industry is the world largest industry and consumes a considerable amount of natural resources and produces a vast amount of waste and pollution (Bohdanowicz 2003). Riding the wave of sustainability, green lodging industry was emerged (Imran Rahman 2012). Component of green lodging industry is green hotels, resorts and chalets.

Initially, green practices of operators are in the area of energy, waste and water. Later the green operators expand their green initiatives in other area such as indoor environmental quality, green materials and resources, sustainable site planning and management, community involvement, biodiversity conservation, human resources development, green transportation, noise control and toxic waste management. The variety areas of the green initiatives are emerged due to the different green certification such as GBI, LEEDS, BREEAM, GREEN MARK, GREEN STAR. Each country has it own green certification system that help hotel operators to be recognized as green operators.

\subsection{Tourism in Malaysia}

Booming of the tourism industry in Malaysia was started in 1990 when Malaysia first organized its 'Visit Malaysia Year'. International tourist arrivals to Malaysia steadily increased year by year due to the wide range of natural asset such as marine parks, lakes, mangroves, limestone caves, waterfalls and tropical forest. Malaysia also represents one of 12 mega diverse countries in the world, which have abundant of floras and faunas (JTLM, 2011). According to Malaysia Tourism Minister Y.B Dato Sri Dr Ng Yen Yen in 2012,"Malaysia is currently recognized by the UNWTO as the world $9^{\text {th }}$ most travelled destination in the world (Ibrahim 2012).

Presently, there are 12 green hotels and resorts in Malaysia. These hotels and resorts won the Green ASEAN Hotel Award in 2012. However, there are many other hotels and resorts in Malaysia, which are practicing green approaches in their operation but are not, recognized as green operators. The operators are willingly practicing green approaches in their operation in order to gain financial benefits and to fulfill corporate social responsibility. For instance, Golden Palm Tree Spa Resort in Sepang (Yusof \& Jamaludin, 2013).

\subsection{Identification of barriers}

Barriers in implementing green operation practices have been discussed by several studies. The main study is conducted by (Chan 2008). This study identified six barriers encountered by hotel operators in adopting the Environmental Management System (EMS) in their operation. The barriers identified are lack of knowledge and skills, lack of professional advice, uncertainty of outcome, lack of certifiers/verifiers, lack of resources, implementation and maintenance costs.

The second pertinent studies is conducted by Kamalulariffin et al. (2013). This study identified five barriers, which are regulation and government, customer demand, level of competition, greenest at the organization level and attitude toward change. The third study 
is by Vikneswaran Nair et al. (2012), which identified nine barriers. The barriers are lack of knowledge, support from guest and owner, maintenance and implementation cost, resources, qualified expert, government support and difficulty in operating green hotel.

From the content analysis of all the related literature, 12 pertinent barriers were identified. The list of the barriers is listed in the Table 1. The first barrier is high implementation and maintenance cost, which are due to the green products and equipment, which is generally expensive. For example, energy saving chiller is more expensive compared to the traditional one. Second and third barrier is regarding the lack of green experts and green knowledge. This is because green practices are a new area in the lodging industry. It will require some time to developed expertise in this area.

The fourth barrier identified is lack of regulation and government enforcement. According to Rivera et al (2009) and Scott (2004) government or regulation is coercive mechanism that exerts pressure on the organization to become green operation. The fifth barrier identified is difficulty in balancing the quality of service with environmental performance. Certain green initiatives reduced the quality of services. Usually guests' expectation is to receive comfort and luxury indulgence during a trip. For example, most of the guests are preferred to have individual shampoo bottles compared to soap dispenser, even though soap dispenser can reduce a significant amount of waste. Studies have also shown that guest agreed to stay in environmental friendly hotels but are not willing to pay extra for the green practices (Manaktola \& Jauhari, 2007).

The seventh barrier is regarding the lack of support from guests, which want green facilities but not willing to pay more. The eighth barrier is lack of support from the owner or top management. Sometimes conflict arose between the client and the top management team which drawback the environmental management system. The success of any business to become green operation is solemnly depending on the client ambition and aspiration.

Table 1: List of barriers identified from literature

\begin{tabular}{l}
\hline Barriers \\
\hline High implementation cost \\
High maintenance cost \\
Lack of green information and knowledge \\
Lack of green experts \\
Uncertainty of outcome \\
Lack of resources such as manpower and equipment \\
Lack of support from owner and management \\
Lack of government regulation and enforcement \\
Difficulty in balancing the quality of service with environmental performance \\
Lack of consumer supports \\
Lack of networking with green suppliers \\
Difficulty in managing and training staffs \\
\hline
\end{tabular}

The ninth barrier is difficulty in managing and training staffs. According to Mandarin Oriental KL manager, it takes a lot of efforts and time to train staffs to become green and understand green practices (Yusof \& Jamaludin, 2013). According to her usually staffs that have been trained for so long resign from their job caused difficulty to the management to 
replace the staffs. The tenth and eleventh barrier are lack of green suppliers, products, equipment and manpower. Green business strategy is new in the market. Therefore, green products, equipment and supplies are limited in the market.

The last barrier identified is uncertainty of outcome of green operation. Many operators uncertain regard the green operation management and the output of the operation, which draw them back to become green operators. They believe that green operation meticulous in process which needs more resources, time and the process (Chan 2008)

\subsection{Methodology}

This study is conducted using qualitative method. Official letter for conducting interview survey was sent to 12 green operators in Malaysia.

\subsection{Introduction to case studies}

Only five green operators agree to take part in this study. The operators are 5 to 4 Star green hotel and resort operators located at Peninsular Malaysia. The operators not agreed to reveal their organization name in this research. The researcher acknowledged the case studies as Hotel $A, B$, and $C$ and Resort $A, B$. The detail information of each case study can be referred in Table 2.

\subsection{Formulation of interview questions}

A set of the questionnaire was prepared based on the 12 barriers identified from the literature. The questionnaire was divided into two parts. In part one, questions were asked regarding the background of hotels and resorts such as location, year of operation, green certification, staffs and room numbers. In part two, 12 questions were asked regarding the barriers. The examples of the question were asked such as- Does the implementation cost was a barrier for this hotel to become a green operator? The environmental managers are requested to give an answer according to dichotomous scale such as Yes or No and give justification for each of the answer.

\subsection{Data collection procedure}

First phase of data collection was reviewing all the related journals in the area of environmental management in the lodging industry. Barriers are identified from the literatures using content analysis method. The second phase of data collection is fieldwork where interviews were conducted with the environmental managers of the each case study. Interview session was recorded and transcribed verbatim. The limitation of this study is the response regarding the barriers is taken from one-person opinion rather than organization response. 


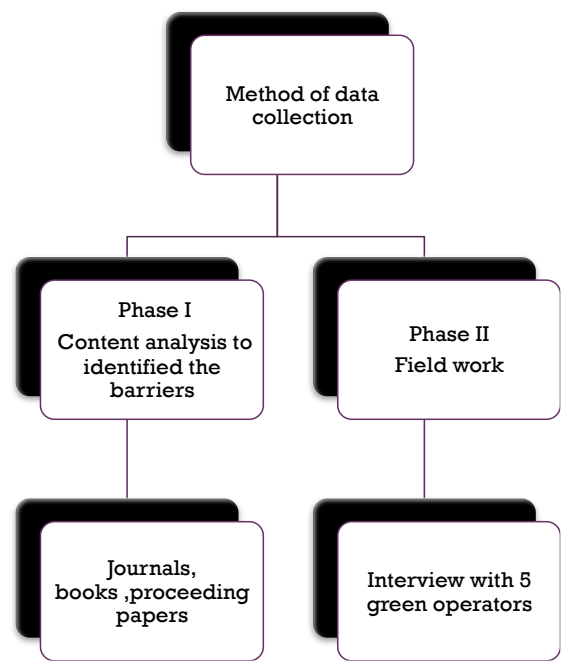

Figure 1: Shows method of data collection.

(Source: Author)

\subsection{Findings and Discussions}

Findings are divided in two parts. The first part is regarding the background of the case studies. The second part is regarding the green operation barriers of the case studies.

\subsection{Background of the case studies}

From the five case studies, three case studies are green hotels and two are green resorts. Basic information of the case studies is listed in Table 2 below.

Table 2: Background of the case studies

\begin{tabular}{|c|c|c|c|c|c|}
\hline Background & Hotal $A$ & Botal 8 & Hods/C & Resort A & Resart $B$ \\
\hline Locesion & $\begin{array}{l}\text { Jolso lobi } \\
\text { Kuals Lumpur }\end{array}$ & $\begin{array}{l}\text { Jolson } \\
\text { Pinsing, } \\
\text { Kuale } \\
\text { Lumpar }\end{array}$ & $\begin{array}{l}\text { Jolso, Sulton } \\
\text { Imsil, Kusis } \\
\text { Lumpar }\end{array}$ & $\begin{array}{l}\text { Ponisi Tengeh, } \\
\text { Largkesii }\end{array}$ & $\begin{array}{l}\text { Jolso, Ayer } \\
\text { Keceb, } \\
\text { Malsoca }\end{array}$ \\
\hline Year of operation & 1985 & $796 \%$ & 7968 & 2006 & 2010 \\
\hline $\begin{array}{l}\text { Green } \\
\text { oertificafon'Lwavd }\end{array}$ & 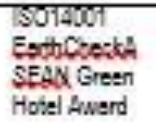 & $\begin{array}{l}\text { SOTADO } \\
\text { ASEAN } \\
\text { Green Hobel } \\
\text { Anard }\end{array}$ & $\begin{array}{l}\text { BSTADOH } \\
\text { ASEAN Green } \\
\text { Hotal Awerd, } \\
\text { HACCP }\end{array}$ & $\begin{array}{l}\text { ASELAN Green } \\
\text { Hotal Award, } \\
\text { PATA Gold } \\
\text { Amerd } 2012\end{array}$ & $\begin{array}{l}\text { Bes: Green } \\
\text { Hoisel Awerd } \\
\text { MTA } \\
20112012\end{array}$ \\
\hline
\end{tabular}

\begin{tabular}{llllll}
\hline No of rooms & 300 & 400 & 862 & 117 & 201 \\
\hline No of sisfis & 170 & 700 & 900 & 120 & 200 \\
\hline
\end{tabular}




\subsection{Barriers faced by green hotel and resort operators in Malaysia}

Summary of the findings for barriers are listed in the Table 3 . The first finding shows that all hotel managers were disagree that there is high implementation cost to become green operator. Where else, the resort managers agreed that there are high implementation costs. The study revealed that the hotels are chain affiliated which have strong financial support from their parent company. Where else, the resorts are not chain affiliated, have a small investment and feel green operation has high operational cost.

The second finding shows that all the managers agreed that there are no problems in getting information regarding the green practices. According to Hotel A manager green knowledge and information are enormous nowadays on the Internet. The third finding shows that top management or owners of hotels and resorts are very supportive towards green operation. Mainly hotels and resorts top management usually decides to become green operators and the rest of subdivision will be followed.

The fourth finding indicates that all the managers agreed that there is lack of green experts and resources such as manpower and green equipment. This is due to the new area of green practices in Malaysia lodging industry, which have less green experts and staffs that understand the new system, products and procedures.

The fifth finding revealed that all managers agreed that they were aware of the outcome of being the green operators. There are many examples of organizational champion worldwide which show the reaping benefits of becoming the green operators. The benefits are in terms of energy, waste and water saving which lead to financial benefits.

The sixth finding indicates that the Hotel $C$ and Resort $A$ agreed that there is lack of government support and enforcement. Where else, the Hotel A, B and Resort B disagreed that there is lack of government support. According to them government are very supportive in their green programs and practices. Where else, the Hotel $C$ and Resort $A$ did not get the same support.

The seventh finding shows that all managers agreed that green operation does not have high maintenance cost. The eighth finding indicates that there are difficulties in balancing the quality of service with environmental performance. All managers agreed that they were facing difficulties in balancing between guests' needs and green practices. For example, Hotel A and Hotel $B$ manager informed that guests does complaints regarding no service of newspaper and shampoo bottles in the rooms. The no newspaper and shampoo bottles in the rooms were one of the green initiatives of hotels and resorts to reduce waste. However, guests like to be pampered during vacation because they paid to have all the services.

However, the ninth finding shows that generally the guests are very supportive towards green operation. According to Hotel B manager only $10 \%$ of the hotel guests are not satisfied with their green operation. According to Manaktola (2007) generally guests are willing to stay and support green hotels initiatives. The tenth finding indicates that there are no problems in having networking with green vendors and suppliers in Malaysia. However, only Resort A manager having difficulty to find green supplier due to the location of the resort, which is located on the island.

The last finding is Hotel A and Resort A does not having problems in managing and giving training to the staffs for green practices. Managing and training staffs were one of the 
barriers for Hotel B, C and Resort B. According to Hotel B manager, some staffs have less commitment towards green practices and tend to resign easily. This is due to extra work and training. Where else, Hotel A and Resort B does not have problems in training their staffs because they have prepared very interesting green programs rather than training. The programs are green competition, art-making program, green school programs and green outing for staffs. These activities encourage the staffs to become more active and interested in practicing green initiatives.

Table 3: Barriers of the case studies

\begin{tabular}{|c|c|c|c|c|c|c|}
\hline Bamers & Hotel A & Hotel $B$ & Hodel C & Resod $A$ & Riesod B & $\begin{array}{l}\text { Level of } \\
\text { signiflest }\end{array}$ \\
\hline High implementetion ose: & No & No & No & Tes & Yes & $\begin{array}{l}\text { Lets: } \\
\text { sigrificart: }\end{array}$ \\
\hline $\begin{array}{l}\text { Loek of green information end } \\
\text { knouledge }\end{array}$ & No & No & No & No & No & $\begin{array}{l}\text { Non } \\
\text { sgrificart }\end{array}$ \\
\hline Lack of gresen experts & Yes & Yes & Yes & $\mathrm{Yes}$ & $\mathrm{Yes}$ & Sgrificant \\
\hline 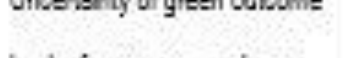 & & & & & & sgrificant: \\
\hline $\begin{array}{l}\text { Lask of resources s.ch as } \\
\text { menpower and esujement }\end{array}$ & Yes & Yes & Yes & Yes & Yes & Sgrificant \\
\hline $\begin{array}{l}\text { Lack of support from carer } \\
\text { end mensgenent }\end{array}$ & No & No & No & No & No & $\begin{array}{l}\text { Non } \\
\text { sigrificant }\end{array}$ \\
\hline $\begin{array}{l}\text { Lack of govemment regalation } \\
\text { and e-forcenent }\end{array}$ & No & No & Yea & Yes & No & $\begin{array}{l}\text { Lets } \\
\text { sigrifivant. }\end{array}$ \\
\hline High maintensnce cost & No & No & No & No & No & $\begin{array}{l}\text { Non } \\
\text { sigrificant: }\end{array}$ \\
\hline $\begin{array}{l}\text { Dificulty in balenoing the } \\
\text { qusilty of service with } \\
\text { environmertai performanos }\end{array}$ & Yes & Yes & Yes & Yes & Yes & Sgrificant \\
\hline Lack of consumes s.pports & No & No & No & No & No & $\begin{array}{l}\text { Non } \\
\text { sigrificant: }\end{array}$ \\
\hline $\begin{array}{l}\text { Lock of nebworking with green } \\
\text { s.ppliers }\end{array}$ & No & No & No & Yes & No & $\begin{array}{l}\text { Non } \\
\text { sgrificant: }\end{array}$ \\
\hline $\begin{array}{l}\text { Cificulty in maraging ond } \\
\text { training staffs }\end{array}$ & No & Yes & Yes & No & Yes & $\begin{array}{l}\text { Lets } \\
\text { sigrificant }\end{array}$ \\
\hline
\end{tabular}

\subsection{Conclusion}

In conclusion, there are three categories of barriers, which are significant, less significant and non-significant. The significant barriers are lack of green experts and lack of resources in term of manpower, green equipment and difficulty in balancing the quality of service with environmental performance. Where else, there are three less significant barriers. The less significant barriers are high implementation and maintenance cost and lack of government support. Where else, there are five non-significant barriers. The non-significant barriers are lack of green information and knowledge, uncertainty of green outcome, lack of support from 
the owner and management, lack of consumer supports and lack of networking with green suppliers. Non-significant barriers mean that green operators in Malaysia did not face that challenges in running their green operation. Where else significant barriers mean that the green operators are facing those particular barriers in running their operation.

Generally the study shows that the green operators in Malaysia only face few barriers to become green operators. This is because they have very good support from their parent company and guests, no uncertainty, have adequate green knowledge and have good green supplier contact. The implication of this study is it will help other hotels operators in Malaysia to understand the barriers that they might face in becoming green operators. In future, this research can be extended to understand barriers faced by small accommodation operators.

\section{Acknowledgement}

IIUM Research Grant (Endowment B) funded this study. This research is a part of corresponding author's PhD study at the Universiti Teknologi Mara Shah Alam Malaysia.

\section{References}

A. Mathieson and G. Wall, (1982). Tourism, Economic, Physical and Social Impacts, Longman, London,

Bohdanowicz, P., \& Martinac, I. (2003). Proceedings from the CIB 2003 International Conference on Smart and Sustainable Built Environment. Attitudes towards Sustainability in Chains Hotel-Results of European Study, Brisbane, Australia.

Bonilla Priego, M. J., \& Aviles Palacios, C. (2008). Analysis of Environmental Statements Issued by EMAS-Certified Spanish Hotels. Cornell Hospitality Quarterly, 49(4), 381-394. doi:10.1177/0010880407307766

Bruntland , G . (ed.) ( 1987 ) . Our Common Future: The World Commission on Environment and Development, Oxford University Press, Oxford .

Chan, E. S. W. (2008). "Barriers to EMS in the hotel industry." International Journal of Hospitality Management 27(2): 187-196.

Claver-Cortes, E. Molina-Azorin, J. F., Pereira-Moliner, J. and Lopez-Gamero, M. D. (2007) Environmental strategies and their impact on hotel performance. Journal of Sustainable Tourism 15 (6): $663-679$.

Elkington, J., Knight, P.(1992). The Green Business Guide. Victor Gollancz, London. Everitt.

Ibrahim, F. (2012). Buletin 1 MOTOUR. U. K. Korporat. putrajaya, Kementerian Pelancongan Malaysia 3.

Jauhari, V., \& Rishi, M. (2012). Challenges faced by the hospitality industry in India: an introduction. Worldwide Hospitality and Tourism Themes, 4(2), 110-117. doi:10.1108/17554211211217299.

Jayawardena, C. (Chandi), Lawlor, F., Grieco, J. C., Savard, M., \& Tarnowski, M. (2013). Challenges and innovations in hotel operations in Canada. Worldwide Hospitality and Tourism Themes, 5(2), 177-189. doi:10.1108/17554211311314128

JTLM. (2011). Pelan Strategik Jabatan Taman Laut Malaysia (pp. 1-45). 
Kamalulariffin, N. S., Nabiha, S., Khalid, A., \& Wahid, N. A. (2013). The barriers to the adoption of environmental management practices in the hotel industry : a study of Malaysian hotels. Bussiness strategy series, 14(4), 106117. doi:10.1108/BSS-06-2012-0028.

Knowles, T., Macmillan, S., Palmer, J., Grabowski, P., Hashimoto, A., (1999). The development of environmental initiatives in tourism: responses from the London hotel sector. International Journal of Tourism Research 1, 255265.

Manaktola, K., \& Jauhari, V. (2007). Exploring consumer attitude and behaviour towards green practices in the lodging industry in India. International Journal of Contemporary Hospitality Management, 19(5), 364-378. doi:10.1108/09596110710757534.

Molina-Azorín, J. F., Claver-Cortés, E., López-Gamero, M. D., \& Tarí, J. J. (2009). Green management and financial performance: a literature review. Management Decision, 47(7), 1080-1100. doi:10.1108/00251740910978313.

Ngai Weng, C. (2009). Ecotourism and Environmental Conservation in Small Islands in the East Coast of Peninsular Malaysia. Malaysian Journal of Environmental Management, 10(2), 53-69.

Rahman, I., Reynolds, D., \& Svaren, S. (2012). How "green" are North American hotels ? An exploration of low-cost adoption practices. International Hospitality Management, 31, 720-727. doi:10.1016/j.ijhm.2011.09.008.

Rivera, J., Oetzel, J., deLeon, P. and Starik, M. (2009), "Business response to environmental and social protection policies: toward a framework for analysis", Policy Science, Vol. 42, pp. 3-32.

Robinot, E., \& Giannelloni, J.-L. (2010). Do hotels' "green" attributes contribute to customer satisfaction? Journal of Services Marketing, 24(2), 157-169. doi:10.1108/08876041011031127

Scott, W.R. (2004), "Institutional theory: contributing to a theoretical research program", Stanford University, available at: http://icos.groups.si.umich.edu/Institutional\%20Theory\%200xford04.pdf Sekaran.

Vikneswaran Nair, \& Anantharajah, S. (2012). A green makeover for our Hotels? Quartely DOE Update on Environment,Development \& Sustainability, (2), 10-12.

Yusof, Z. B., \& Jamaludin, M. (2013). Green Approaches of Malaysian Green Hotels and Resorts. Procedia - Social and Behavioral Sciences, 85, 421-431. doi:10.1016/j.sbspro.2013.08.371 